\title{
PELATIHAN PROSES PEMBUATAN BISKUIT DARI TEPUNG PEPAYA DAN PISANG G DI DESA SILO, JEMBER
}

\section{TRAINING OF BISCUIT MAKING PROCESS FROM PAPAYA AND BANANA POWDERS IN SILO VILLAGE, JEMBER}

\author{
Aji Sukoco ${ }^{\# 1}$, Septy Handayani\#2 \\ ${ }^{\# 1,2}$ Department of Agricultural Product Technology, Faculty of Agricultural Technology, University of \\ Jember \\ Kalimantan Street 37, Tegalboto Campus, Jember 68121 \\ 1ajisukoco@unej.ac.id \\ ²septyhandayani02@unej.ac.id
}

\begin{abstract}
Abstrak
Desa Silo adalah salah satu daerah pertanian potensial di Kabupaten Jember, khususnya sebagai daerah penghasil buah pepaya. Akhir-akhir ini, penjualan buah pepaya terhambat karena stok pasar masih tinggi. Ini memaksa petani untuk kehilangan penghasilan, dan masalah yang sama juga terjadi pada petani buah pisang. Akibatnya, stok pepaya dan buah pisang berlimpah di Desa Silo, dan petani kesulitan menjual komoditas itu. Oleh karena itu, program pengabdian masyarakat ini dilakukan untuk menginisiasi peluang bisnis bagi masyarakat di Desa Silo khususnya bagi petani melalui pelatihan proses pembuatan biskuit dengan memanfaatkan buah pepaya dan pisang. Sekitar 28 anggota Gerakan Kesejahteraan Keluarga Desa Silo bergabung dalam program pengabdian masyarakat ini. Implementasi program pengabdian masyarakat terdiri dari pendekatan dan pengumpulan data peserta, persiapan peralatan dan materi pelatihan, kegiatan pelatihan, dan pendampingan peserta. Hasil dari program pengabdian masyarakat menunjukkan bahwa para peserta antusias dan aktif selama pelatihan karena mereka memperoleh wawasan baru yang bisa menjadi solusi untuk menyelesaikan masalah ekonomi petani di Desa Silo. Para peserta cukup terampil membuat biskuit karena peralatan yang digunakan sederhana dan mudah dioperasikan, serta aditif makanan yang digunakan mudah ditemukan di pasaran. Evaluasi sensorik menunjukkan bahwa panelis lebih suka biskuit yang terbuat dari bubuk pepaya dan pisang daripada yang dibuat dari salah satu bubuk itu. Ini menunjukkan bahwa buah pepaya dan pisang dapat diolah menjadi bentuk biskuit, yang akan menjadi peluang bisnis yang bagus bagi para petani di Desa Silo.
\end{abstract}

Kata kunci- Bubuk pisang, biskuit, bubuk pepaya, Desa Silo

\section{Abstract}

Silo Village is one of the potential agricultural areas in Jember Regency, where is particularly known as the papaya fruit producing regions. Lately, sales of papaya fruit are hampered because the market stock is still high. It forces farmers to lose their income, and the same problem also happens to the farmers of banana fruit. Consequently, there is an abundant stock of papaya and banana fruits in Silo Village, and farmers have difficulties to sell those commodities. Therefore, this community service program was carried out to initiate the business opportunity for society in Silo Village especially for farmers through the training of biscuit making process by utilizing papaya and banana fruits. About 28 members of the Family Welfare Movement of Silo Village were joined in this community service program. The implementation of the community service program consisted of approaching and collecting data of collection, preparation of training equipment and material, training activities, and accompaniment of participant. The result of the community service program showed that the participants were enthusiastic and active during training because they gained new insight that could be used as a solution to solve the economic matter of farmers in Silo Village. The participants were quite skilled to bake a biscuit because the equipment used was simple and easily operated, as well as the food additive used was easily found on the market. The sensory evaluation demonstrated that the panelist preferred the biscuits made from papaya and banana powders than made from one of those powders. This indicated that the papaya and banana fruits could be processed into biscuit form, which would be a great business opportunity for those farmers in Silo Village.

Keywords - Banana powder, biscuit, papaya powder, Silo Village 


\section{INTRODUCTION}

Silo Village, Silo District, Jember Regency is one of the districts with its potential target in agricultural production. Silo District was a region with the highest amount of legal certified-agricultural industries, which were as much as seven industries[1]. This district was reported as the region with the highest number of agricultural household business about 20.989 households. Silo District was also recorded as one of the main producers of avocado and papaya fruits [2].

Based on the information obtained from the initial survey, there was no problem in the production and sale of avocado fruit, but in contrast, the sale of papaya and banana were massively hampered. The overstock of papaya and banana in the market forces farmers to leave their crops in the farmlands. Further, these fruits are highly perishable due to temperature, humidity, physical treatment, or other storage conditions, so the range of its expansion is limited. Sometimes the farmers just offered those fruits to the surrounding residents at a very low price, or in other words, they were willing to lose money. Therefore, a new breakthrough should be taken to handle the problem in a sensible way, for example, food diversification. Diversify food from papaya and banana fruits can be applied to fulfill the need for nutritious food product along the rising in health awareness among the population.

Biscuit is a baked food product made from wheat flour, egg, sugar, butter, and other food additives, and it is cooked with using oven at a certain temperature and time. Many people prefer to eat biscuits as a breakfast or add them to the beverage and blend it. In addition, the proper processing of papaya and banana fruits become biscuit is also aimed to increase the shelf-life of the product, so the farmers can expand their market in a longer distance without limited by time.

Some problems of the partner of this program were also identified based on the survey, 1) there was no idea to create the good formulation and biscuit making process, 2) there was no save technology available in Silo Village to prepare the powders of papaya and banana. Our partner just thought that selling those fruits to the market was a good idea than giving a benefit (added value) to increase the selling price. Therefore, the authors as a team of community service program provided training of biscuit making process made from papaya and banana powders for the Family Welfare Movement members of Silo Village. By improving the skill of the Family Welfare Movement members, a small business idea can be started. The team of community service program also guided the new business to be very selective in the pursued opportunities.

\section{TARGET AND OUTPUT}

The participant of this program was members of the Family Welfare Movement of Silo Village, Silo District, Jember Regency. The purpose of the program given was to solve the problem faced by the farmers of papaya and banana fruits in Silo Village. By processing those fruits become biscuit eventually will support the increase of healthy food consumption in Silo Village, Silo District. Further, this biscuit is expected to be a candidate for healthy food with nutritionally more complete than other commercial biscuits. In addition to assist the participant in improving their skills, the team of community service also provides the powders of papaya and banana fruit according to the need of participant. This coverage helps all participants to enhance their business to produce the innovative biscuit continuously.

The output of this program was members of the Family Welfare Movement had the fundamental skills and knowledge they need to make a biscuit with better taste. Other outputs were publication in printed and electronic media (published), as well as a scientific article that will be published by the journal of community service.

\section{METHODS}

The community service program in Silo Village, Silo District, Jember Regency was performed for three months by the following stages:

\section{A. Approachment and data collection of participant}

These activities were started by visiting Silo Village to get the communication with Village head of Silo and did a survey in the farm. The team of community service program was instructed to meet the Head of the Family Welfare Movement of Silo Village because the training given was suitable for them. The team of community service program then recorded the Family Welfare Movement members of Silo Village according to their ID card. About 28 members of the Family Welfare Movement were recruited in this training, and they were further instructed by the Head of the Family Welfare Movement to set the time of the training. The Head of the Family Welfare Movement then offered the schedule to the team of the community service program to reach the appointment. Some students of Agricultural Product Technology Department were also involved in this program to escort the participant in practicing biscuit making process. 


\section{B. Preparation of training equipment and material}

The team of community service program prepared the training material such as guidance book, papaya and banana powders, and food additives. The village officials provided Training room, LCD projector, and whiteboard. The member of the Family Welfare Movement provided electric oven, mixer, stove, and other required tools.

\section{Training activities}

Training was held at Silo village meeting hall on Tuesday, November 27, 2018. The guidance book was given to the participant before opening time, so they could read it and understand how it would benefit them. In this training, the training team gave the explanation to the participant about the content of guidance book before practicing. The content of the book was the background of training, papaya and banana powders making process, biscuit making process, and feasibility analysis. The discussion was thereafter given for few minutes. All participants were allowed to convey the question or confusing statement. The training team or participant could give the feedback.

In the practice activity, the participant was divided into 6 groups and each group consisted of four to five persons. There were three recipes of biscuit, namely papaya biscuit (papaya powder + wheat flour), banana biscuit (banana powder + wheat flour), and papaya-banana biscuit (papaya powder + banana powder + wheat flour). Two groups did one similar recipe. At the end of the training, the participant also evaluated the level of preference on the three different biscuits. The training team employed rating hedonic test form to obtain the representative score.

\section{Accompaniment of participant}

The team of community service program accompanied the participant in developing biscuit formulation and marketing strategy. The participant who would like to try a new taste desired the formulation improvement program. High motivation of the participants encouraged them to make a new product such as pastry, cake, and donut by still utilizing papaya and banana powders. This wide range of bakery products would attract more customers and eventually had the kind of income that businessperson want. In addition, the team also guided the participant to understand the most effective marketing and advertising tools. For instance, the packaging design of the product should contain complete and clear information.

\section{RESULTS AND DISCUSSION}

The members of the Family Welfare Movement of Silo Village showed high interest and enthusiasm on the training given (Figure 1). The Head of the Family Welfare Movement revealed that they were very pleased to follow the training and were obsessed with the idea as a new alternative. Many participants did not know that papaya and banana fruits can be processed become biscuit. There are many health benefits to be gotten from this biscuit due to its nutrient comes from those fruits that other commercial biscuits might not. The fruits powder (papaya and banana) making process is depicted in Figure 2.

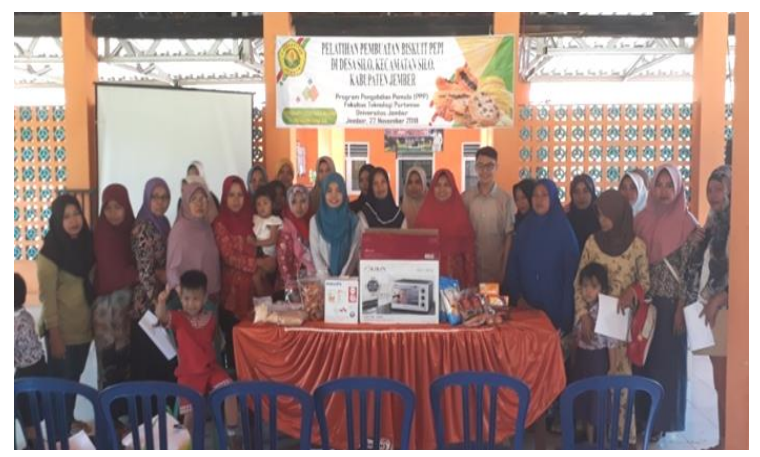

Figure 1. Training of biscuit making process in Silo Village

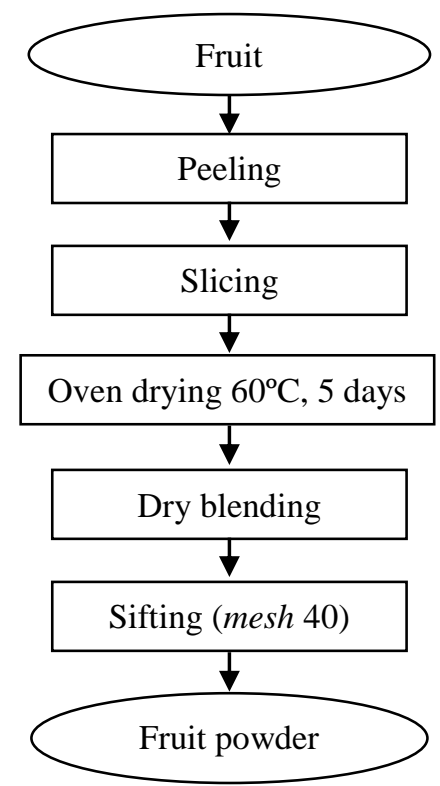

Figure 2. Flow chart of a fruit powder making process

Local papaya variety of Thailand was used in this training due to their large plantation scale in Silo Village. The condition of the papaya fruit was halfripe and not rotten as a way of keeping the biscuits fresh and long shelf-life. A really good flavor is also expected. About $300 \mathrm{~g}$ of papaya powder was produced from $5 \mathrm{~kg}$ of papaya fruit. This means that the yield resulted was $6 \%$ and it indicates that papaya fruits have high water content. Figure 3 shows the papaya powder obtained.

Banana powder (Figure 4) was produced from local banana variety of Kepok. The farmers in Silo Village commonly planted this variety. Half-ripe banana and not rotten was used to ease the powder 
processing and produce a brighter color with a good aroma. As much as $912 \mathrm{~g}$ of banana powder was produced from $2 \mathrm{~kg}$ of banana fruit, so the yield obtained was $45.6 \%$. This yield was higher compared to the yield of papaya powder. However, the participants still face an obstacle in producing those fruit powders because there is no large-scale oven in Silo Village. Therefore, the team of community service program will help them by providing papaya and banana powders so that biscuits can be made continuously.

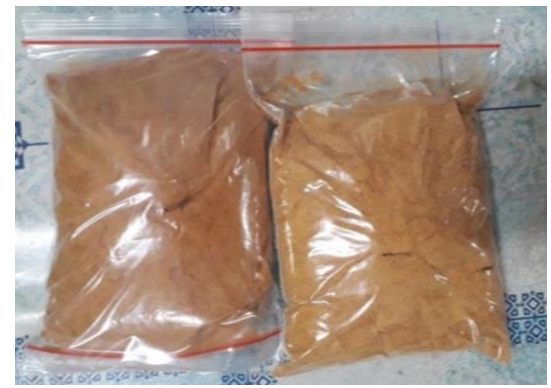

Figure 3. Papaya powder

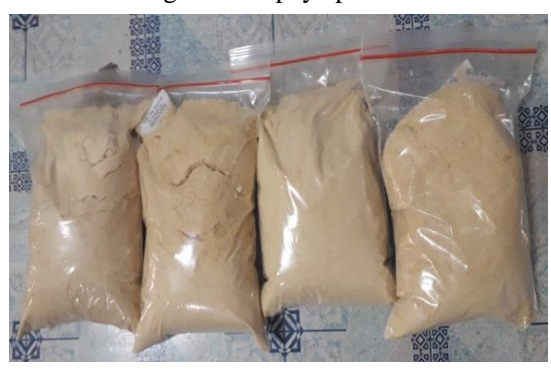

Figure 4. Banana powder

Both fruit powders can be processed into various biscuit choices. The ingredients of each biscuit are shown in Table 1. The ratio of wheat flour substitution was suited to the type of biscuit. The ratio of 50:50 (wheat flour:papaya/banana powder) was used to make papaya biscuit or banana biscuit, while the ratio of 30:30:40 (papaya powder:banana powder: wheat flour) was used to make papayabanana biscuit.

TABLE I

BISCUIT FORMULATION

\begin{tabular}{|l|c|c|c|}
\hline \multirow{2}{*}{ Ingredient } & \multicolumn{3}{|c|}{ Types of biscuit } \\
\cline { 2 - 4 } & Papaya & Banana & $\begin{array}{c}\text { Papaya- } \\
\text { Banana }\end{array}$ \\
\hline Papaya powder (g) & 43.75 & 0 & 26.25 \\
\hline Banana powder (g) & 0 & 43.75 & 26.25 \\
\hline Wheat flour (g) & 43.75 & 43.75 & 35 \\
\hline Cornstarch (g) & 15 & 15 & 15 \\
\hline $\begin{array}{l}\text { Powdered sugar } \\
\text { g) }\end{array}$ & 30 & 30 & 30 \\
\hline Powdered milk (g) & 15 & 15 & 15 \\
\hline Baking powder (g) & 1 & 1 & 1 \\
\hline Butter (g) & 50 & 50 & 50 \\
\hline Margarine (g) & 50 & 50 & 50 \\
\hline Yolk (g) & 15 & 15 & 15 \\
\hline
\end{tabular}

The following instruction outlines the mixing and forming, and the baking process of the biscuit:

a) Weigh all ingredients needed and measure them by gently spooning it into a cup

b) Place the margarine, butter, and powdered sugar into the container.

c) Mix them using a mixer for about three minutes until cohesive dough is formed.

d) Add yolk into the dough.

e) Mix well until just about combined for about three minutes.

f) Add wheat flour into the dough.

g) Add papaya powder and or banana powder into the dough (according to the type of biscuit).

h) Add cornstarch, baking powder, and powdered milk into the dough.

i) Mix them manually using a spatula (without a mixer). Do not overwork the dough to prevent the dough be very crumbly.

j) Cut the dough into desirable form with a sharp knife or other nice-sized biscuits.

k) Add chocolate chips in the top of formedbiscuit dough.

1) Bake the biscuits in the oven at $\pm 145^{\circ} \mathrm{C}$ for \pm 38 minutes. Remove from the oven if biscuits are golden brown on top.

Figure 5 demonstrates the result of sensory evaluation of three different types of biscuit. The result showed that the aroma produced among three biscuits was significantly different. The aroma of the banana biscuit was the most liked by the panelist (member of the Family Welfare Movement) and was followed by papaya-banana biscuit and papaya biscuit. Overall attribute showed that the panelist preferably to papaya-banana biscuit, papaya biscuit, and banana biscuit, respectively. This indicates that the papaya-banana biscuits are organoleptically acceptable by society and marketable.

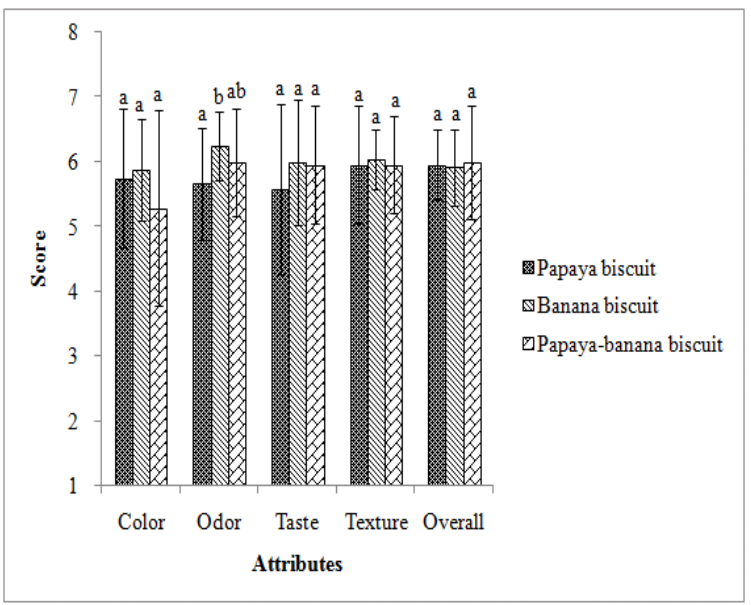




\section{CONCLUSION}

\section{A. Conclusion}

This community service program improves the fundamental knowledge and skill of the Family Welfare Movement members of Silo Village to make biscuit from papaya and or banana powders. In addition, this alternative can be a solution to open a new small business because biscuits made from the combination of papaya and banana powders are acceptable organoleptically.

\section{B. Suggestion}

This program should be developed by providing other methods to process papaya and banana fruits become many other preserved products such as candy, jellies, jams.

\section{ACKNOWLEDGMENTS}

This community service program was supported by the Center of Research and Community Service University of Jember (LP2M UNEJ) through the program of Hibah Internal 2018.

\section{REFERENCES}

[1] Badan Pusat Statistik. 2013. Hasil sensus pertanian 2013. Jember: Badan Pusat Statistik.

[2] Komarayanti, S., 2017. Ensiklopedia buah-buahan lokal berbasis potensi alam Jember. Jurnal Biologi dan Pembelajaran Biologi, 2(1), pp.61-75. 